\title{
REFLECTIONS AND AUTOBIOGRAPHIES
}

\section{Reflections}

\section{Anne Aburn}

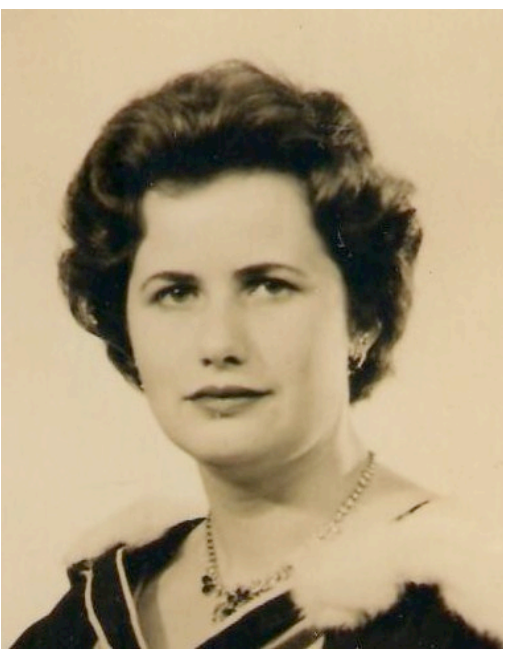

Anne Aburn is the Senior Practitioner (Adoptions \& Caregiver) Wairarapa / Tararua.

Much has already been written about ANZASW and its development and achievements over the past 50 years. Rather than write a formal paper, I would like to reflect on the beginnings of the Association back in the early 1960s.

I began my social work career as a 'Social Science Cadet' under the guidance of Jack Luckock.

Jack Luckock was a contemporary of Mervyn Hancock. He and his wife Gay (nee Vause) were in the second intake of the Victoria University Diploma of Social Science in 1951. Jack became a Senior Officer in the Head Office of the Child Welfare Division and Gay was a Child Welfare Officer. When the Social Science Cadetship scheme was implemented Jack became the Supervisor of the cadets, arranging and monitoring their placements etc.

The Social Science Cadetship was a scheme set up under the auspices of the Public Service Commission. Selected young people, working in government welfare departments, received study awards enabling them to complete a Bachelor's degree at university while gaining work experience in those agencies. On completion of their degrees it was anticipated most would further their studies with a Diploma in Social Science. Some of the other cadets were Kara Puketapu, Esther Zander, Vel Puke and Anne Taylor (now Frankland.)

Jack and Gay moved to Auckland and for a time Jack was a Senior Boys Welfare Officer in the Auckland Child Welfare Office, which at that time covered the whole Auckland district. When new offices were opened in Takapuna and Otahuhu, Jack became District Child Welfare Officer at Otahuhu.

During the time I was a Social Science Cadet and also while at the School of Social Science, I had a number of practical placements which took me all round New Zealand. As a cadet I began in the Head Office of the Department of Maori Affairs, where I had nearly a year as the Assistant Editor of the Te Ao Hou magazine. This was followed by a summer placement in Kaikohe with the Maori Welfare Division - Bay of Islands one day then over to Hokianga the next. From there it was to Auckland and Child Welfare for a year, then a short time at both Fareham House, a girls' training centre, in Featherston and Anglican Social Services in Christchurch. 
While at the School my summer placement was at Queen Elizabeth Hospital in Rotorua. During my second year I had one day a week in the Wellington Probation Office and another day at Arohata Borstal.

When I moved to Palmerston North at the end of 1961, having just completed the twoyear Diploma in Social Science at Victoria University of Wellington, I became one of the first (of what were then known as) Welfare Officers for the Social Security Department.

Soon after my arrival in Palmerston North I became part of an informal Central Districts group.The main objective of the group was to work on a co-operative basis where we had clients known to many of us. Our group consisted mainly of Mervyn Hancock (Child Welfare), Tom Austin (Probation), Bertha Zurcher (Hospital), Jean Barrett (Child Health Clinic), Dennis Garrett (Education) and myself.

It is well known that the idea to form a national organisation for social workers was Merv Hancock's brainchild. At that time, Merv was the District Child Welfare Officer in Palmerston North and soon, with his enthusiasm and boundless energy, he had inspired us with his idea of having a New Zealand-wide organisation for all social workers, not only those in government departments, but also voluntary agencies. Previously, while in Dunedin, Merv, together with Arch Eliffe, had formed an Otago Association of Social Workers. Groups had also been set up in other districts. So, having these contacts, Merv canvassed social workers throughout the country. There was a consensus that there should be some formal national association, so he started the ball rolling.

Our original Palmerston North group became a local steering committee. By then I had moved from social work to motherhood, but I continued to participate in meetings, as I was doing some voluntary supervision for the Probation Service. Other Child Welfare and Probation staff were co-opted as required, one of them being Gary Hermansson.

I was given the task of compiling mailing lists, which entailed contacting as many social work agencies as possible and asking for the names of all their staff. We had names of those involved in the district groups and were able to access names of those working in statutory agencies. When working in the Department of Maori Affairs, I had compiled a National Directory of Social Services, so I already had the addresses of all the voluntary agencies, big and small.

Most of our meetings were held in the Probation office and as I had a small son I brought him with me and sat him in a carton with some toys while compiling lists of names. Letters were sent out and from then on it was a matter of setting a date for the inaugural meeting. This was held in Auckland in February 1964 and, as they say, with Mervyn being elected as the first president and Arch Eliffe as the first secretary, 'The Rest is History!'

I did not participate in the inaugural meeting, but did attend the first Biennial Conference at Massey University in February 1966. As is also known, Mervyn and Ephra Garrett later established the Bachelor of Social Work degree course at Massey University.

Although not working, I continued to take an interest in the association, but did let my membership lapse until I returned to work in Child Youth and Family, Masterton when the 
Adult Adoption Information Act was introduced in 1986. I have been working in the adoption field ever since. This has been the most rewarding aspect of my social work career and I am pleased to have been part of a programme that has enabled so many people to reclaim their original identity. In 2010 I wrote a paper for all Adoption Social Workers, Twenty five years of adult adoption in New Zealand - 1985-2010 - An overview of adult adoption since the implementation of the Adult Adoption Information Act 1985.

As there was no local ANZASW branch in Masterton at the time I returned to work, at the request of a member of the Wellington branch I arranged the first meeting of local social workers in 2000 and a Wairarapa branch was formed. Although it went into recess temporally (2005), I have been an active member ever since.

In 2013, I was, together with Lynette Stutz, recognised by the local branch for my years of service.

Maybe it is time to retire! 